\title{
Analysis of the scope of thermo-modernization for a residential building in order to transform it into a low-energy building
}

\author{
Maciej Knapik ${ }^{1, *}$ \\ ${ }^{1}$ Institute of Thermal Engineering and Air Protection, Faculty of Environmental Engineering, Cracow \\ University of Technology
}

\begin{abstract}
The article presents the problem of thermo-modernization and the reduction of energy demand for heating purposes in existing residential buildings. The thermo-modernization process has to adapt the existing building to the standard of a building with low energy demand and applicable regulations. Low-energy constructions are a result of introduction of new solutions in building design process. Their main objective is to achieve a significant reduction in demand for renewable primary energy, necessary to cover the needs of these buildings, mostly related to their heating, ventilation and domestic hot water. The article presents the results of the analysis and calculation of selected thermomodernization variants. The results showed that thermo-modernization process of existing residential buildings is justified both energetically and economically.
\end{abstract}

\section{Introduction}

Existing buildings, especially those built in the 1970s and 1980s, are characterized by an increased energy demand for heating purposes. In these buildings the energy demand for the heating purposes seems to be of a much higher proportion in relation to the total energy demand of the building. In order to reduce the demand for energy and adaptation of existing buildings to the standard of a building with a low energy demand[1-3], depending on the case, the appropriate thermo-modernization packages should be implemented, which might significantly improve the energy balance of the building. In residential buildings, heat losses depend mainly on insulation of building envelope (including thermal bridges), ventilation efficiency of the building or type of used windows [1-4]. Fig. 1 shows the percentage distribution of the heat loss in an existing building (a weak thermal parameters).

The use of appropriate thermo-modernization packages as improved insulation of building envelope or the use of mechanical ventilation system with heat recovery can significantly reduce heat losses and adapt the building to the standard of a building with a low energy demand. The modernized building significantly reduces the consumption of non-renewable energy sources, and therefore the negative impact on the environment is reduced. The optimally carried out thermo-modernization process can reduce the annual

${ }^{*}$ Correspondingauthor: maciek.knapik@gmail.com 
energy demand for heating purposes up to $60 \mathrm{kWh} / \mathrm{year} / \mathrm{m}^{2}$, reaching the standard of a low energy building $[1,2,5,6]$.

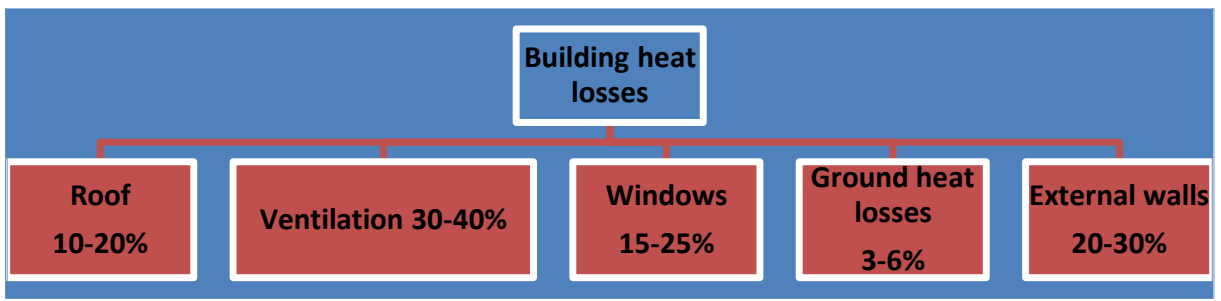

Fig. 1. Percentage distribution of the heat loss in an existing building.

\section{Energy characteristics of the building from the 1980s}

In order to perform heat losses calculations, Audytor OZC software was used. The prepared calculation is based on PN EN standards[7, 8]. The calculation takes into account the annual energy demand based on PE EN standard [9].

Analysed building, built in the technology of the $1980 \mathrm{~s}$, is located in the $3^{\text {rd }}$ Polish climate zone. Building envelope is characterized by high heat transfer coefficients U. The building uses a natural ventilation system and traditional wooden windows. It is necessary to adopt a few assumptions to perform calculations as summarized in Table 1.

Table 1.Assumptions regarding the building partitions, based on [10].

\begin{tabular}{|c|c|c|c|}
\hline Partition & Layers & $\begin{array}{c}\text { Heat transfer } \\
\text { coefficient } \mathbf{~} \\
{\left[\mathbf{W} / \mathbf{m}^{\mathbf{2}} \mathbf{K}\right]}\end{array}$ & $\begin{array}{c}\text { Total area of } \\
\text { partitions } \\
{\left[\mathbf{m}^{\mathbf{2}}\right]}\end{array}$ \\
\hline $\begin{array}{c}\text { External } \\
\text { walls }\end{array}$ & $\begin{array}{c}\text { Plaster, brick, air layer, plaster, } \\
\text { styrofoam, plaster }\end{array}$ & 0.52 & 465 \\
\hline Roof & $\begin{array}{c}\text { Sheet metal, screed, polyethylene, } \\
\text { styrofoam, concrete, plaster }\end{array}$ & 0.83 & 90 \\
\hline $\begin{array}{c}\text { Floor on the } \\
\text { ground }\end{array}$ & $\begin{array}{c}\text { Terracotta, concrete, polyethylene, } \\
\text { concrete }\end{array}$ & 0.62 & 227 \\
\hline $\begin{array}{c}\text { Windows } \\
\text { and doors }\end{array}$ & Windows and doors from the 1980s & 1.8 & 40 \\
\hline $\begin{array}{c}\text { Interior } \\
\text { ceilings }\end{array}$ & Oak, concrete, styrofoam, concrete, \\
\hline $\begin{array}{c}\text { Interior } \\
\text { walls }\end{array}$ & Plaster & 0.61 & 454 \\
\hline
\end{tabular}

The degree-day value [11] was used to calculate the annual energy cost savings. Degree days of heating are defined as the difference between the design indoor temperature and the average monthly external air temperature. Number of degree days can be calculated as follows:

$$
S d=\Sigma\left(t_{w o}-t_{e(m)}\right)^{5 / 3} \cdot L d(m)
$$

where:

$S d$-the degree-day value, $\mathrm{K} \cdot$ day

$t_{w o}$-average design internal temperature (for rooms, kitchens and bathrooms), ${ }^{\circ} \mathrm{C}$

$t_{e(m)}$-monthly average outside air temperature, ${ }^{\circ} \mathrm{C}$

$L d$-number of heating days in a given month, day

$m-$ month of the year. 
On the basis of the applicable regulations [12-14] and building characteristics, a certificate of energy performance of the building was prepared [15]. The result of the analysis is presented in Fig. 2.

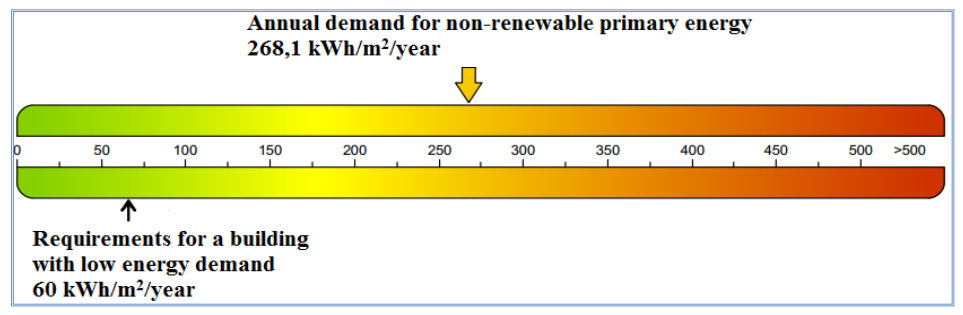

Fig.2. Results of the energy performance of the analyzed building based on [13].

It can be seen that the building is characterized by a very large index of the annual demand for non-renewable primary energy EP in relation to the applicable regulations [13].

As a result of the calculations, it was determined that the energy demand for heating purposes during the year for the analyzed building is $370 \mathrm{GJ} / \mathrm{year}$.

\section{Thermo-modernization packages}

The thermo-modernization process and its economy are different for each case, depending on the adopted conditions and requirements which should be achieved after the modernization of the building. Thermo-modernization packages include all possible combinations of 5 thermo-modernization variants, which are summarized in Table 2.

Table 2. Variants of thermo-modernization process.

\begin{tabular}{|c|c|}
\hline Variant of thermo-modernization & Symbol \\
\hline External walls insulation & 1 \\
\hline Roof insulation & 2 \\
\hline Replacement of windows & 3 \\
\hline Replacement of doors & 4 \\
\hline Mechanical ventilation with heat recovery & 5 \\
\hline
\end{tabular}

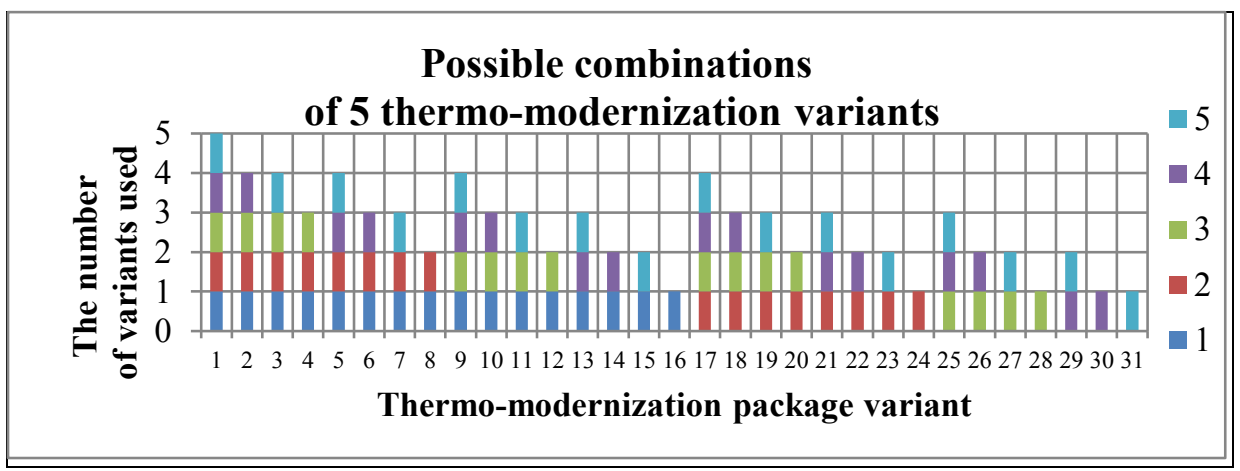

Fig.3. Combinations of 5 variants of thermo-modernization.

On the basis of Fig. 3 and maintaining signs(symbol), Fig. 3presents all possible combinations of 5 variants, which formed 31 thermo-modernization packages. 


\subsection{External walls insulation}

Analyzed energy savings resulting from changing the thickness of external wall insulation (styrofoam) are presented in Fig. 4. For each analyzed insulation thickness, a simple payback time (SPBT) can be calculated as follows:

$$
S P B T=I / A I
$$

where:

$S P B T$ - simple payback time, year

$I$-investment costs, PLN

$A I$-average annual investment income (after considering operating costs), PLN/year.

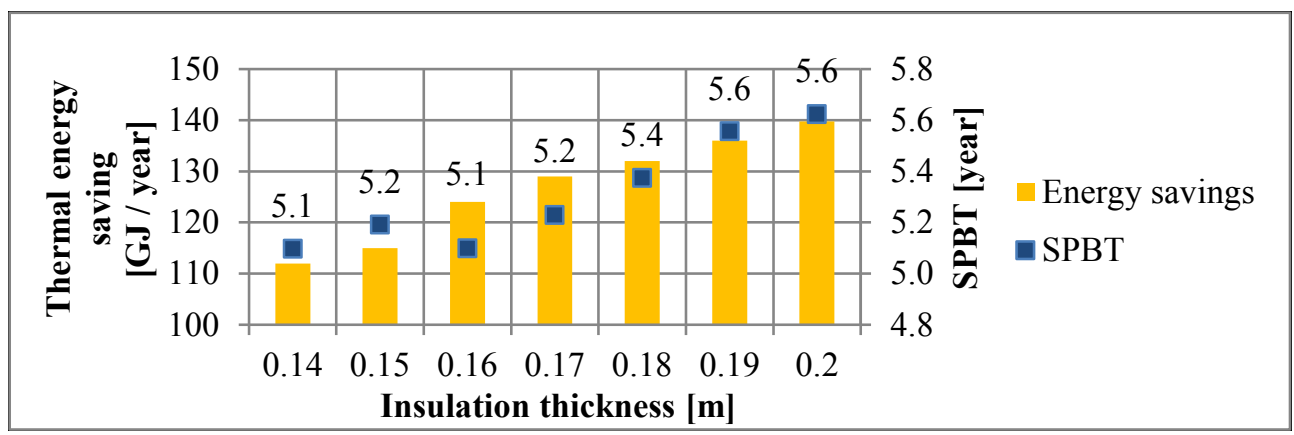

Fig.4. Thermal energy savings resulting from changing the thickness of external wall insulation and its profitability.

The results presented in Fig. 4 show the optimal external wall insulation thickness for the analyzed case which is $0.16 \mathrm{~m}$. Simple payback time is 5.1 years. The first criterion for selecting the optimal solution is SPBT, and secondly the amount of energy saved (if the SPBT result for the different variants is the same).

\subsection{Roof insulation}

The results from improving roof insulation (mineral wool) are presented in Fig. 5.

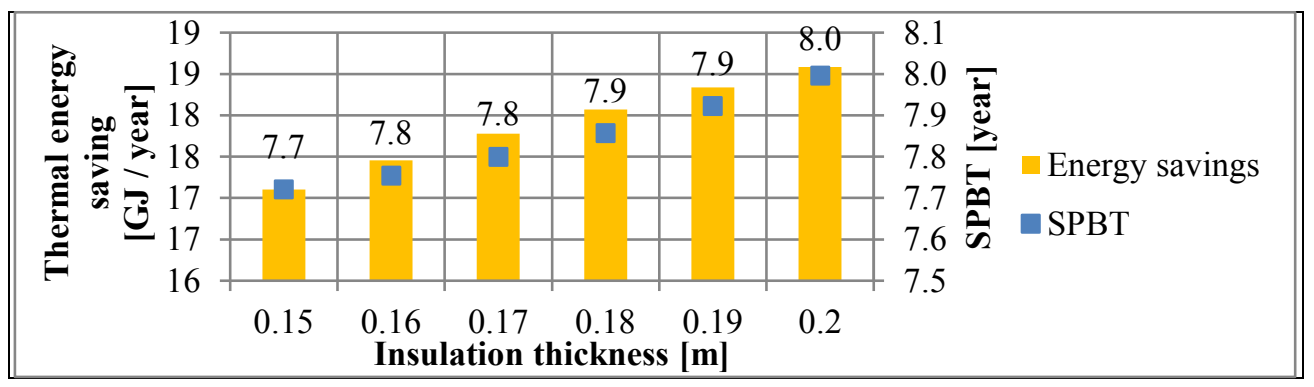

Fig.5. Thermal energy savings resulting from changing the thickness of roof insulation and its profitability.

The results presented in Fig. 5 show the optimal roof insulation thickness for the analyzed case, which is $0.15 \mathrm{~m}$. The simple payback time is 7.7 years. 


\subsection{Replacement of windows}

Fig. 6 presents the energy savings analysis resulting from replacing windows to achieve better heat transfer coefficient $U$.

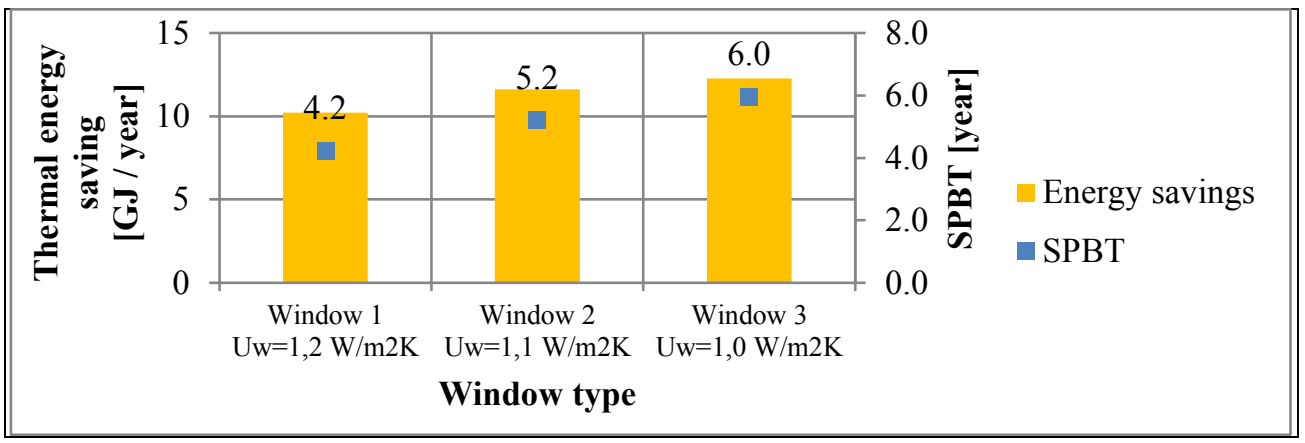

Fig.6. Thermal energy savings resulting from windows replacement and its profitability

The results presented in Fig. 6 show the optimal windows for the analyzed case are windows with heat transfer coefficient $\mathrm{U}=1.2 \mathrm{~W} / \mathrm{m}^{2} \cdot \mathrm{K}$. The simple payback time is 4.2 years. Replacing the windows on the tight one is not conducive to the free exchange of air in the rooms. Therefore, to maintain proper air circulation, it is recommended to use mechanical ventilation system or to install vents in the windows.

\subsection{Replacement of doors}

Results of energy savings analysis resulting from external door replacement, for doors with a better heat transfer coefficient $\mathrm{U}$ are presented in Fig. 7.

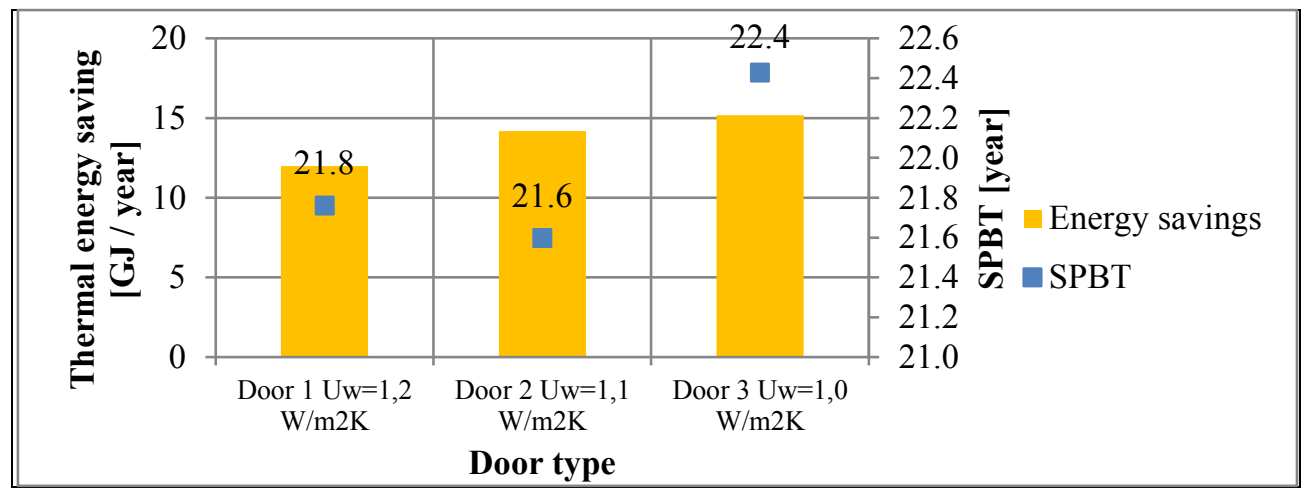

Fig.7. Thermal energy savings resulting from external door replacement and its profitability.

The results presented in Fig. 7 show the optimal external doors for the analyzed case are doors with heat transfer coefficient $\mathrm{U}=1.1 \mathrm{~W} / \mathrm{m}^{2} \cdot \mathrm{K}$. The simple payback time is 21.6 years. 
In order to achieve the standard of a low-energy building, it is recommended to use mechanical ventilation system with heat recovery. The energy benefits resulting from the use of mechanical ventilation compared to natural ventilation are reduced when considering the electricity demand to power the fans. Natural ventilation is unpredictable and does not work in many situations $[16,17]$.

The results of energy savings resulting from mechanical ventilation with heat recovery are presented in Table 3 .

Table 3. Thermal energy savings resulting from mechanical ventilation with heat recovery and its profitability.

\begin{tabular}{|c|c|}
\hline Description & Results \\
\hline Energy savings [GJ/year] & 87 \\
\hline SPBT [year] & 2.3 \\
\hline
\end{tabular}

Mechanical ventilation with heat recovery does not make sense if the building is not sealed and there is uncontrolled air exchange.

If the house has the ability to execute the mechanical ventilation system with heat recovery it should be advised to implement it. For the analyzed case simple payback time is less than one year (assuming that the building uses gas fuel for heating, the costs of electricity for power the fans and the fixed costs of using the system, such as annual maintenance services).

\section{Results}

The results presented in Fig. 8 show annual demand for non-renewable primary energy $\mathrm{kWh} / \mathrm{year} / \mathrm{m}^{2}$ for all possible combinations of 5 variants, which formed 31 thermomodernization packages.

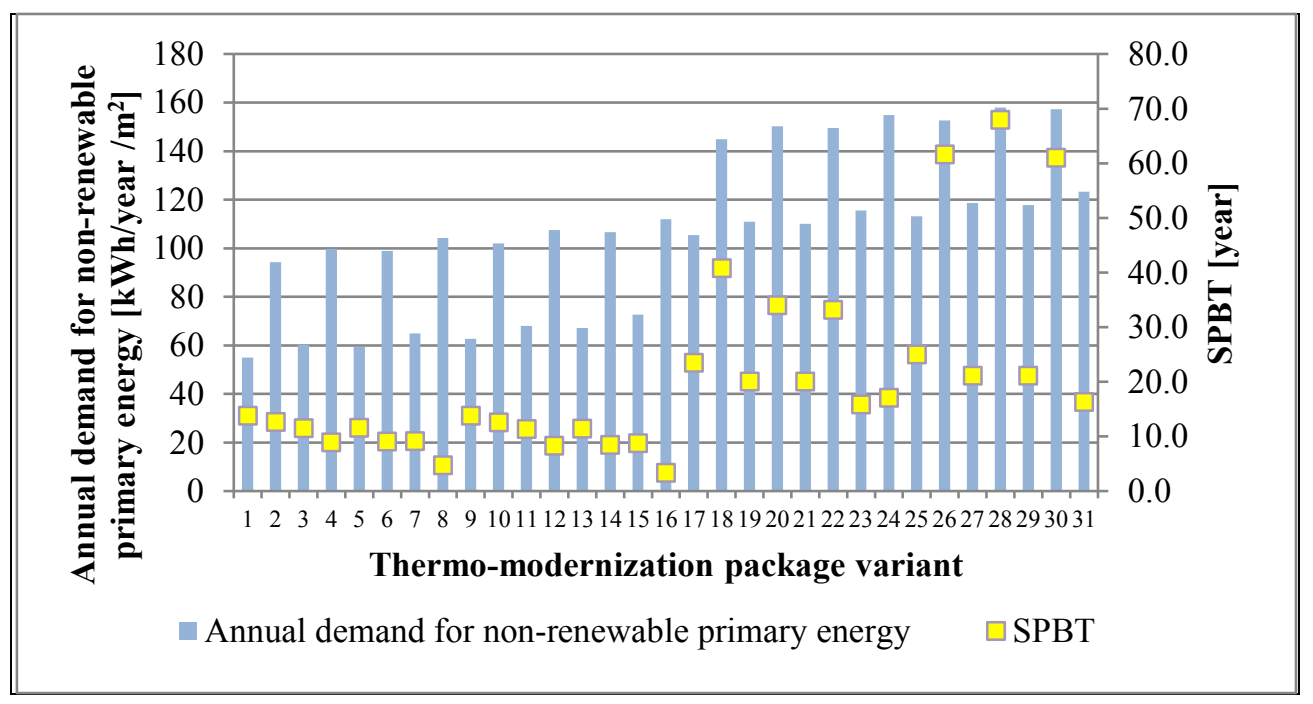

Fig.8.Annual demand for non-renewable primary energy for each variant and its profitability.

The results presented in Fig. 8indicated that the only 3 variants from 31 makes it possible to achieve a standard of a building with a low energy demand. These are variants of 1,3 and 5, reaching a result less than or equal to $60 \mathrm{kWh} / \mathrm{year} / \mathrm{m}^{2}$. 
From an economic point of view, the best results of SBPT achieve variants 3 and 5(11.6 years).

From an energetic point of view, the best result of thermal energy saving achieve variant 5 (228 GJ/year).

Variant 3 assumes no replacement of the external doors and variant 5 assumes no replacement of the windows.

In order to preserve the sense of mechanical ventilation with heat recovery, the proper tightness of the building should be ensured, therefore windows and doors should be replaced for a new one/building.

For the analyzed case, with the assumptions made, the most advantageous thermomodernization package is option 1 , assuming all thermo-modernization variants.

\section{Conclusions}

Analysis allowed achieving the standard of a building with a low energy demand (no more than $60 \mathrm{kWh} /$ year $/ \mathrm{m}^{2}$ ).

The standard of a building with low energy demand for the analyzed case was achieved only with 3 thermo-modernization packages out of 31.The use of the appropriate set of thermo-modernization packages can significantly reduce energy demand for heating purposes in existing residential buildings.

The aim of the study was to analyse the thermo-modernization variants to achieve a low-energy building compliant with current standards. The analysis took into account the thickness of the insulation of external walls and the roof. Depending on the thickness of the insulation, optimal results were found which were characterized by the lowest SPBT value.

Thermo-modernization analysis also took into account the replacement of external door and windows, as well as the use of mechanical ventilation with heat recovery. It must be noted that mechanical ventilation with heat recovery does not make sense if the building is not sealed and there is uncontrolled air exchange.

If the house has the ability to design mechanical ventilation with heat recovery it should be designed.

Therefore, along with the design of mechanical ventilation with heat recovery, the replacement of windows and doors, which will protect against uncontrolled air flow and related with this heat losses should be implemented.

Analyses allow concluding that, it is preferable to use advantageous thermomodernization packages, which can significantly reduce energy demand for heating purposes. The economic effect of analysis can be observed in Fig. 8, where SPBT for analyzed case can reach 11.6 years. Due to the reduced demand for energy for heating purposes, the demand for non-renewable energy sources is also reduced, while reducing the emission of exhaust gases to the atmosphere, and therefore reducing the adverse impact on the environment.

\section{References}

1. W. Feist, U. Münzenberg, J. Thumulla, Podstawy budownictwa pasywnego (ISBN 83923807-0-3, 2009)

2. E. Rylewski, Energia własna(ISBN 83-917314-2-1)

3. M. Knapik, Rynek Instalacyjny 9,36-38(2016)

4. G.Hua, V.R. McClung, S.Zhang, Energy and Buildings 60, 163-173(2013)

5. F. Stevenson,Building Research \& Information 41, 5,605-608(2013) 
6. D.I. Kolaitis, E. Malliotakis, D.A. Kontogeorgos, I. Mandilaras, D.I. Katsourinis, M.A. Founti,Energy and Buildings 64, 123-131(2013)

7. PN-EN ISO 6946:2017-10: Komponentybudowlane i elementybudynku - Opórcieplny i współczynnikprzenikaniaciepła - Metodyobliczania

8. Polish standard, PN-EN 12:831 - 2006: Instalacjeogrzewcze w budynkach Metodaobliczaniaprojektowegoobciążeniacieplnego

9. PN-EN ISO 52016-1:2017-09: Energetycznewłaściwościużytkowebudynków Zapotrzebowanie na energię do ogrzewania i chłodzenia, wewnętrznetemperaturyorazjawne i utajoneobciążeniacieplne -- Część 1: Proceduryobliczania

10. Polish standard, PN-82-/B-02020: Ochrona cieplna budynków. Wymagania i obliczenia

11. PN-B-02025:1999:Obliczaniesezonowegozapotrzebowania na ciepło do ogrzewaniabudynkówmieszkalnych

12. Rozporządzenie Ministra Infrastruktury z dnia 17 marca 2009 r. W sprawie szczegółowego zakresu i form audytu energetycznego oraz części audytu remontowego, wzorów kart audytów, a także algorytmu oceny opłacalności przedsięwzięcia termomodernizacyjnego

13. Rozporządzenie Ministra Infrastruktury i Budownictwa z dnia 14 listopada 2017 r. zmieniające rozporządzenie $\mathrm{w}$ sprawie warunków technicznych, jakim powinny odpowiadać budynki i ich usytuowanie. Dziennik Ustaw (2017)

14. Rozporządzenie Ministra Infrastruktury z dnia 6 listopada 2008 r. w sprawie metodologii obliczania charakterystyki energetycznej budynku i lokalu mieszkalnego lub części budynku stanowiącej samodzielną całość techniczno-użytkową oraz sposobu sporządzania

15. PN-EN ISO 52003-1:2017-09: Energetycznewłaściwościużytkowebudynków -Wskaźniki, wymagania, ocena i certyfikacja -- Część 1: Ogólneaspekty i zastosowanie do całkowitychenergetycznychwłaściwościużytkowych

16. H.Recknagel, E. Sprenger, E.R. Schramek, Ogrzewnictwo, klimatyzacja,ciepła woda, chłodnictwo(OMNISCALA, Wrocław, 2008)

17. J. Kwiatkowski, A. Panek,Criteria For Low Energy Buildings [online], www.integrateddesign.eu/downloads/sb13graz_paper_JK_ADP.pdf(Access: 28.01.2018) 